\title{
ON THE SO-CALLED METAMORPHISM OF THE TRIAS IN THE ALPS
}

Sir,-Many readers must have welcomed $O$. T. Jones's article under the above title in the Geological Magazine, 1948, p. 333. It recalls metasomatic effects of weathering which concern us all, whether our interest be general or particular, in which latter case it may be focused on such matters as soil or laterite, including bauxite, or the leaching and secondary enrichment of metalliferous ores. I could not help being reminded of my own "Subterranean Penetration of a Desert Climate", published in your pages in 1926; and even more of J. E. Richey's account in the Geological Survey Memoir on Ardnamurchan $(1930$, p. 35) of phenomena associated with Triassic cornstones: "These chemically-formed limestones, deposited from solution, are at some localities found at the base of the Trias, and in this position they are seen to have permeated and partly replaced the underlying quartzose and felspathic schistose rocks in an intricate manner. The lime-bearing solutions have attacked the schists more especially along their beddingplanes, so that cornstone is found interleaving with these much more ancient rocks." Richey then points out that other Triassic examples of the same phenomenon had been described by myself in 1925 from Inch Kenneth, off Mull, and by Albert Heim in 1920, from an Alpine locality-he might also have added by Clough in 1910 from Skye, in the Geological Survey Memoir on Glenelg, p. 91. A more recently discovered locality has been described by me from Rhum, in a Quarterly Journal paper, 1945 (for 1944), p. 175. Partial replacement of schist by limestone at the base of a cornstone (here of Upper Old Red Sandstone or Lower Carboniferous date) is also capitally exposed at Loch Ranza in Arran. The locality is famous because it furnished James Hutton in $\mathbf{1 7 8 5}$ with an example of angular unconformity. Hutton's description in his third volume of The Theory of the Earth, not published till 1899 , is very restrained in regard to the metasomatic phenomena. The rocks above and below the unconformity are, he says, "somewhat confused at the immediate junction."

19 Greenhill Gardens,

E. B. Bailey. EDINBURGH.

18 th December, 1948.

\section{STUDIES IN THE MONA COMPLEX-THE BASE OF THE BEDDED SUCCESSION}

SiR,-In the Anglesey Memoir (p. 168), an opinion was expressed, which was proven decisively in $1923^{1}$; that between the Bedded Succession and the Gneisses there must be an unconformity, and of the first magnitude. Yet, on p. 169, I add "but this unconformity has never been found, and within the limits of Anglesey, has probably been cut out everywhere by thrusting ". Is that, however, probable? In our chapter on the Succession we traced a number of horizons which, if cut out locally, did escape at other places. Why should this one never escape? How did I come by such an opinion? I think it was that really I was expecting a basal conglomerate, with boulders of the gneisses, and never finding such a bed, supposed that I had not reached the base. There was a still stronger reason. When I wrote that sentence, although (see table on p. 164, Anglesey Memoir) I had come to realize that the Fydlyn Beds were the lowest known member of the Bedded Succession, they had not been recognized to the north of the Carmel Head thrust plane. Not long afterwards they were, as shown in my paper of 1923. And the matter

${ }^{1}$ Quart. Journ. Geol. Soc., lxxix, 334-351. 